\title{
Towards Understanding Listening Comprehension in EFL Classroom: The Case of the Saudi Learners
}

\author{
Farah Bano ${ }^{1}$ \\ ${ }^{1}$ English Language Institute, Women's Campus, King Abdulaziz University, Jeddah, Saudi Arabia \\ Correspondence: Farah Bano, English Language Institute, P.O.Box 80200, Women's Campus, King Abdulaziz \\ University, Jeddah, 21589, Saudi Arabia. E-mail: fmalik@kau.edu.sa
}

Received: March 1, 2017 Accepted: May 20, 2017 Online Published: May 26, 2017

doi: 10.5539/elt.v10n6p21 URL: http://doi.org/10.5539/elt.v10n6p21

\begin{abstract}
The present study aimed at making a pedagogical exploration into listening comprehension skills and examining the problems faced by learners in the English as a Foreign Language (EFL) classroom situation at Jazan University, Jazan city, Saudi Arabia. To analyze the problems, two very important processes were considered; namely, top-down and bottom-up process. The top-down process worked well because of their previous knowledge of the context to make sense of what is being said in the class. However, the bottom-up also worked as well.
\end{abstract}

Keywords: pedagogical exploration, listening comprehension, EFL classroom, top-down, bottom-up

\section{Introduction}

Listening involves understanding a speaker's accent or pronunciation, his/her grammar and vocabulary, and grasping his/her meaning. There are four skills taught in the EFL classroom, reading, writing, speaking, and listening. They are all very important skills in the EFL classroom. But many researchers believe that the most important two skills are Listening then speaking. Therefore, teaching the listening skill should be considered an important component of the language learning. As Bress (2006) points out that of all the four skills, listening must surely be the most practiced one. We start listening as babies and awfully indulge in it before we even start to speak. In the context of EFL and English as a Second Language (ESL), Bress (2006) has pointed out that the more one understands, the more one feels confident. However, if we look at the classroom situation, it is usually disappointing to find that teaching of listening is mostly neglected in our language classroom (Bress, 2006). The neglect is not because we do not recognize the importance of listening, but because we take it for granted that learners automatically acquire this skill without imparting any training. Hence, for many years, listening skills occupied the lowest part in practical language teaching. Language teaching, for several years, placed emphasis on productive skills and the relationship between the receptive and productive skills was poorly understood. Nunan (2002) has quite aptly captured this subordinate status of listening skills. According to him "Listening is the Cinderella skill in second learning. All too often, it has been overlooked by its older sister speaking......... being able to claim knowledge of a second language means being able to speak and write in that language" (p. 238). He further argues that learners and teachers of the second language feel that listening and reading are secondary skills -"means to other ends rather than ends in themselves" (p. 238).

\subsection{Introduce the Problem}

Generally speaking, many ESL learners find that they are unable to comprehend natural spoken English delivered at normal speed. This piece of research tries to report a study of listening problems encountered in the EFL classrooms at Jazan University, Saudi Arabia.

\subsection{Purpose of the Study}

The present study aims to make a pedagogical exploration into the listening comprehension skills and to examine the problems faced by learners in classroom situations at Jazan University, by following two important processes namely top-down and bottom up. Tsui (1998) explores:

1). What is the status of the listening skill in the EFL classroom?

2). What is the attitude of the teachers towards listening in the EFL classroom? 
3). What is the attitude of the students towards listening in the EFL classroom?

\subsection{Significance of Background of the Study}

The study will look at EFL learners' strategies, features of the listening texts, and attitudes of the listeners, the task to be completed as a result of understanding, the listening texts, and the degree of written support for the aural input. It will show how the learners in EFL classrooms experience a range of listening problems that can be overcome by using various techniques which help the learners tackle the problems of listening comprehension.

\subsection{Literature Review}

Listening is so common in our everyday life that we tend to ignore it, although it is a vital mental capacity which enables us to understand and communicate with people around us. Listening involves both social and cognitive process - that is, our relationships with people and the way we structure our internal knowledge.

\subsection{Listening Skill in the Language Teaching and Learning}

Listening is one of the essential key factors for the success in daily communication. Morely (2001) points out that: "Listening is used for more than any other single language skill in normal daily life. On average, we can expect to listen twice as much as we speak, four times more than we read, and five times more than write (p. 70).

As part of child's language abilities in normal sequence it is the listening that comes first, and then after some time, the child begins speaking. Reading and writing come very late when the child goes to the school, normally at the age of six. In language teaching and learning, listening skill should be treated with more concern. Bress (2006) points out that of all the four skills, listening must surely be the most practiced one. We start listening as babies and we do an awful lot of it before we even start speaking. The more they understand, the more powerful they feel and the more confidence they have in their ability to communicate a language. Harmer, (2001) points out that: "Listening.....is important since it provides the perfect opportunity to hear voices other than the teachers', enables students to acquire good speaking habits as a result of the spoken English they absorb, and helps to improve their own pronunciation" (p228). According to Morely (2001) are Listening as a skill is neglected in the curriculum at many schools and universities. Teachers and students are concerned about the ultimate goal (i.e speaking). They do not pay enough attention to listening comprehension, which is the "easiest" way to develop speaking. Teachers and students are only looking for the outcomes.

\subsection{The Place of Listening Skills in the Language Learning}

According to Brown (1994), "the importance of listening in language learning can hardly be overestimated" (p. 233). Rost (2000) also points out the importance of listening as "the most widely used language skill" (p. 7) and in practicing this important skill, learners can have their acquisition processes enhanced. However, historically, the listening skill has been neglected both from a research and a pedagogical perspective (Flowerdew, 1994) and one of the reasons why listening is not so commonly emphasized in EFL classes is that teachers tend to give too greater importance to the speaking skill. The lack of listening practice may be due to the fact that the communicative approach method, largely used in language schools nowadays, requires conversation more than other skills. Conaway points out (1982), that listening has been regarded as the most widely used language skill in the classroom and it plays an important role in one's academic success than reading skill or academic aptitude. Murcia (2000) states that: "Listening comprehension lessons are a vehicle for teaching elements of grammatical structure and allow new vocabulary items to be contextualized within a body of communicative discourse" (p. 70). In fact, listening is used far more than any other language skill in normal daily life. In spite of its importance, listening ability development has received only slight emphasis in language instruction (Thanajaro, 2000). The role and importance of listening skills in language learning has always been undermined by many applied linguists. Not only that they ignored the nature of listening in a second language, but rather, have also often believed that the listening skills could be acquired through exposure and therefore, teaching it was not really required. Lately, there has been a shift in the stance and now the scholars of applied linguistics have started showing an active interest in the role of listening comprehension in second language acquisition. Richards and Renandya (2002) have observed that: “.....by the development of powerful theories of the nature of language comprehension, and by the inclusion of carefully developed listening courses in many ESL programs....some applied linguists [have gone] so far as to argue that listening comprehension is at the core of second language acquisition and therefore demands a much greater prominence in language teaching" (p.235). If one traces the position of listening in the history of language learning, one finds that listening has, every so often, come into fashion. It received boost in 1960s when oral language skills were emphasized. Again, it became in the 1980s when Krashen's (1982) ideas about comprehensible input gained prominence. Later, it was reinforced by Asher's Total Physical Response (TPR). TPR theory was developed by Asher (1965) a professor of Psychology at San 
Jose State University, California. It emphasizes on developing comprehension skills before the learner is taught to speak. It shares the belief with several different comprehension based language teaching proposals that:

(i) Comprehension abilities precede productive skills in learning a language,

(ii) The teaching of speaking should be delayed until comprehension skills are established, and

(iii) Skills acquired through listening transfer to other skills.

Work in the field of first language also encouraged the proponents of listening in a second language. Brown (1990), for instance, underlined the importance of developing oracy (i.e the ability to listen and speak) as well as literacy in school. This shift in emphasis was important. Prior to this, the first language learners were only required to taught reading and writing skills. Teaching how to listen and speak was never on agenda because as Nunan points out, "these skills were automatically bequeathed to them as native speakers" (Richards \& Renandya, 2002, p. 238).

\subsection{Listening Comprehension Practice in the Classroom}

Ur (1999) points out that the objective of listening comprehension practice in the classroom is to enable the students to learn to function successfully in real-life, listening situations.

\subsection{Theories of Listening Comprehension in Language Learning}

\subsubsection{Listening Comprehension as Primary Channel for Language Input and Acquisition}

Asher's (1969) Total Physical Response Approach featured a long pre- production phase in which students listened, followed commands and demonstrated their comprehension through non-verbal actions. The Natural Approach of Krashen and Terell (1983) (cited in Brown, 2001) also sets a pre-speech period for listening only. They defined a three-stage process. The first one is the pre-production stage [which] is the development of listening comprehension skill. According to Nord (1981), reception should precede production, because reception enables production. While it is possible to learn to understand without speaking, it is not possible to learn to speak without understanding (cited in Peterson, 2001). According to Peterson (2001), there are considerations for a teacher to make the classroom effective for the second language students: No other type of language input is as easy to process as a spoken language, received through listening. At the beginning stages of language study, before students have learned to read well, it is by listening that they can have the most direct connection to meaning in the new language.

\subsubsection{Listening Comprehension as Multi - Level, Interactive Process of Meaning Creation}

When good listeners involve themselves with any type of spoken discourse, several processes work on various levels simultaneously to provide an understanding of the incoming speech. The higher-level processes (top-down) are driven by the listener's expectations and understandings of the context, the topic, and the nature of the world. The lower level processes (bottom-up) are triggered by the sounds, words and phrases which the listener hears as he or she attempts to decode speech and assign meaning.

\subsection{Listening in a Second Language}

Long (1989) points out that Learning to listen in a second language is more difficult than in the first language. While learning to listen in the first language requires considerable cognitive development and regular attention to social and linguistic input over a period of time, it is not so in second language. On the contrary, it is confounded by a number of difficulties ranging from social psychology to neurological. There are certain studies by Lynch (1988) which demonstrates that the processes are similar. Both first and second language made similar types of mistakes There is no evidence to suppose that second language is in any fundamental way different from first language listening, only in that the second language listeners have a limited knowledge of the language, which is compensated by transfer from their first language.

\section{Experimental Design}

The present study aims to make a pedagogical exploration into the listening comprehension skill and to examine the problems faced by learners in the EFL classroom at Jazan University by following two important processes namely top-down and bottom-up. The present study will focus on the nature of the problems and difficulties faced by the learners when they listen to English. It explores the following questions:

1). What is the status of the listening skill in the classroom?

2). What is the attitude of the teachers towards listening?

3). What is the attitude of the students towards listening? 


\subsection{Subjects of the Study}

In this study, we selected female participants only. The reason was purely experimental. In our study, we included students of semesters 1 and 2. The total number was twenty-four. The female teachers were also included in this study and there were eight teacher participants in total, four teachers from each semester.

\subsection{The Procedures}

The procedures followed in the study focused on presenting two types of data that were obtained from the respondents in classroom situations. These two types of data are as follows:

\subsubsection{Classroom-Based Data}

The data based on classroom observation carried information regarding the extent of listening being practiced in the classroom. Also, out of the four skills, which one is preferred most and what is the status of the listening skill in the classroom. The classroom situations were used to generating data out of classroom based observation. That was a particular classroom situation in which English as a second or foreign language was taught.

\subsubsection{Interview -Based Data}

Informal interview was conducted for eliciting attitude of teachers towards the listening skill. All of them were supportive and willing to discuss their experiences with us at an informal level. Also, included in the interview-based data, were the responses of both learners and teachers involved in the learning and teaching of English language. Their responses were elicited to know which of the skill is closely related to English as second foreign language teaching in the classroom in order of preference.

\subsection{Test Materials}

Since this study is both experimental and observational type, the following techniques were used for eliciting the data from our respondents as well as the teachers:

\subsubsection{Anonymous Observation}

Sometimes our presence affected both the teaching and the students' response. When the teachers asked questions to the students, they became conscious in giving their answer in front of us. We merely observed the classroom behavior and noted down our observation in the field diary. In few cases where we had established some close familiarity with teachers and students. The data was personally recorded by us.

\subsubsection{Classroom Teaching Recordings}

In this scenario, we used tape recorders and made our recordings by being present in the classrooms. For this purpose, good quality audio recorders were used. Considerable attention was given on recording even the extra-linguistic features like backchannel, murmuring, coughs, long silences, and irrelevant comments. I did this recording with the help of one of the administrative staff. The recording was only of teaching English skills. There were several sessions attended but were of few minutes each because they were all becoming irritated and I found it natural reactions.

\subsection{Partial Dictation}

For testing the ability to understand short utterances on a literal level dictation and partial dictation tasks were administered to our respondents. In the partial dictation part of what the respondents hear was already written down for them.

\subsection{Sources of Data}

There were two sources for obtaining the data. It was obtained on the basis of intensive listening and extensive listening.

\subsubsection{Intensive Listening}

In intensive listening we deal with classroom teaching. Here we selected classroom teaching, which is a very important one. In this situation both the teachers and students were part of the classroom where the teacher was a speaker and student was a listener. We examined the problem the students faced while being taught English as a second/foreign language.

\subsubsection{Extensive Listening}

Here the students were asked to listen and write what they listened word by word.

\section{Data Analysis}

To test the ability to understand short utterances, dictation task and partial dictation task were administered. 


\subsection{Dictation Task}

Dictation is an excellent mean to improve students' listening and writing skills. They got an opportunity to hear and pay attention to listen to learn about writing conventions, and also, ideas related to other disciplines which can improve their handwriting and spelling. It proves usefulness for students whose first language is not English. Dictation exercises were based on a text which was familiar to students. It was selected from their subject course book. Here a short passage was taken because they required concentration. The text was read to the listeners at normal speed so that they could improve their comprehension. The dictation part was to improve listening comprehension and spelling abilities. We observed that initially, students were quite slow at taking dictation, because they were not fond of dictations. But after some time, they started showing great improvement. The results showed that initially when the teacher explained the meaning of the difficult words and composed few sentences, which were not complex, but simple sentences matching, the students' level, all these helped them improve their listening abilities and generated enough motivation and interest among them. These are important considerations for listening comprehension tasks and contribute positively towards improving the listening ability.

\subsection{Partial Dictation Task}

Partial dictation was given to test the listening comprehension and to see if it can help improve the listening ability of the students. In partial dictation part of what the students know was already written down for them. Ideas of getting partial dictation were new to our respondents and they displayed much enthusiasm and interest when this test was administered. The steps taken in administering dictation test were also repeated here. The results showed that this test contributed immensely towards listening comprehension and is quite useful in improving listening ability. For testing the ability to understand longer texts, several comprehension exercises were served to our respondents from their course book.

\subsection{Testing Knowledge of the Language}

\subsubsection{Minimal Pairs}

Here the minimal pairs were given in de-contextualized words. The respondents were made to listen to two or three words to indicate whether they were the same or different. This exercise helps in developing not only the pronunciation skills but also comprehension and recognition skills. Here, minimal pairs were given to distinguish minor differences between English vowel sounds. List of minimal pairs was introduced by writing on the board, for example,

Sit-set-sat

Cut-caught

Sing-sang

Our respondents were asked to identify two vowels sound which they wanted to focus on and identify them in the examples below:

$\begin{array}{ll}\text { call } & \text { curl } \\ \text { export } & \text { expert } \\ \text { lawn } & \text { learn } \\ \text { walk } & \text { work } \\ \text { left } & \text { laughed } \\ \text { empire } & \text { umpire } \\ \text { many } & \text { money }\end{array}$

Here teachers made students to practice comprehension skills by using the lists of minimal pairs. When the students while practicing became comfortable with the sounds they started reading sentence. Here, the students were asked to identify which word of each pair was used in the sentence.

\subsection{Observations Based on Classroom Situation}

The type of classroom situation was used for generating the data out of classroom - based observation:

Classroom situation in which the English language was taught. Although the medium of instruction is English, some of the teachers were regularly found using Arabic(L1) for imparting instructions in the classrooms. Arabic was used not with a view to familiarizing the students with textual difficulties but move with a view to 
cultivating feel of ease and sense of relaxation in the classroom environment. There were certain textual difficulties which were neither explained through the use of spoken language nor were simplified by providing equivalent expressions in learners L1. In order of preference, it is followed by writing, speaking and listening skills. However, when it comes to teaching language, the most important skill is reading followed by speaking and writing. Listening skills, according to most of the respondents, were not required to be taught separately as "it is passively being received by us," and "most of the communication time is spent in listening." Teachers' response was almost the same. However, the teachers differed in their responses with regard to language teaching in the classroom. They, by and large, expressed the need to teach listening skill but it may not be "over emphasized" in particular.

\section{Conclusions and Suggestions}

To analyze the problems, two very important processes were considered, namely, top-down process and bottom-up processes. It was found that top-down process worked well as our respondents regularly used their previous learning of the context to make sense of what is being said in the class. They were able to understand the course book well after repetition of lessons, which became clear from studies conducted on them. However, the bottom-up process did not prove effective, because our respondents were well versed in English skills and in English structure after revising and memorizing it on a regular basis. Hence, not much decoding required to understand the input from the smallest meaningful units to complete texts. They were already able to derive the meaning from the context.

\subsection{Pedagogical Implications}

The research pedagogical implications that can be drawn from the proposed study could be used to improve the learners' listening comprehension indirectly through task designs and other listening tasks. Nevertheless, there appears to be poorly understood the relationship between receptive and productive skills. The results of the present study may have several pedagogical implications.

\subsection{Suggestions}

To have a background knowledge is a key feature of any kinds of listening materials if the language learner wants to improve their listening comprehension should acquire the knowledge, structure and vocabulary items they can use in everyday situations.

In teaching and learning process, two aspects play important roles, one is the delivering capacity of the teachers and the other one is the receiving capacity of the students. Without these two aspects, the teaching learning process will not be a successful one.

\section{References}

Bress, P. (2006). Listening Skills: What are they and how do you teach them. Modern English Teacher, 15.1.

Brunched. (1994). Teaching by Principle. Prentice Hall Regents.

Conaway, M. (1982). Listening: Learning to and retention agent. In K. Espalier, \& W. Algier, (Eds). Improving Reading and Study Skills. San Francisco: Jossey-Bass.

Chastain. (1988). Developing Second Language Skills Theory and Practice. Harcourt Javanovich press.USA.1988

Flowerdew, J. (1994). Academic Listening. Research Perspectives. Cambridge University Press.

Harmer, J. (2008). The practice of English Language Teaching. Addison Wesley Publishing Company Essex-

Imbizos. (2000). Schema in literature: Towards a model of comprehension pedagogy. New Delhi: Manak Publications Pvt. Ltd.

James, J. A. (1969). The Total Physical Response Approach to Second Language Learning. The Modern Language Journal, 53(1), 3-17. https://doi.org/10.1111/j.1540-4781.1969.tb04552.x

Krashen, S. D. (1982). Principles and practice in second language acquisition. Fairview Park: Pergamon.

Longed. (1989). Second Language Listening Comprehension: a schemata theoretic perspective. Modern Language Journal, 73, 32-40. https://doi.org/10.1111/j.1540-4781.1989.tb05307.x

Morley, J. (1995). Academic listening comprehension instruction: Models, principles, and practice. In D. Mendelsonand, \& J. Rubin (Eds). A guide for the teaching of second language listening. San Diego: Dominie Press.

Murcia. (2001). Tracing the history: Listening and language learning. In M. Celce, \& Murcia (Eds). Teaching 
English as a Second or Foreign Language. (p. 70). US: Thomson Learning Press.

Peterson. (2001). Skills and Strategies for proficient listening. In M. Celce, \& Murcia (Eds), Teaching English as a Second or Foreign Language (pp. 88-89).

Richards, J. C., \& Renandya, W, A, (Eds). (2002). Methodology in Language Teaching: An Anthology of Current Practice. Cambridge. Cambridge University Press. https://doi.org/10.1017/cbo9780511667190

Rost, M. (1994). Introducing Listening. London: Penguin.

Thanadar. (2000). Using authentic materials to develop listening comprehension in the English as second language in a classroom

Tsui, A. B. M.,\& Fullilove, J. (1998). Bottom-up or Top-down processing as a discriminator of L2 Listening Performance. Applied Linguistics, 19(4), 432-451. https://doi.org/10.1093/applin/19.4.432

Ur, P. (1994). Teaching Listening Comprehension. Cambridge: Cambridge University Press.

\section{Copyrights}

Copyright for this article is retained by the author(s), with first publication rights granted to the journal.

This is an open-access article distributed under the terms and conditions of the Creative Commons Attribution license (http://creativecommons.org/licenses/by/4.0/). 